\title{
Discretion, Due Process, and the Prison Discipline Committee
}

\author{
N.E. Schafer
}

\section{Suggested citation}

Schafer, N.E. (1985). "Discretion, Due Process, and the Prison Discipline Committee." Paper presented at the annual meeting Academy of Criminal Justice Sciences, Las Vegas, NV, Apr 1985.

\section{Summary}

Prison discipline received considerable attention from both the courts and professional organizations during the decade of the 1970s. It was widely assumed that the due process requirements which resulted from judicial review coupled with the promulgation of model discipline standards and procedures would limit the broad discretionary authority found in the traditional prison disciplinary process. A case study of the activities of one prison discipline committee suggests that these external pressures have had less impact on decision-making than such internal pressures as overcrowding. Due process requirements have not greatly inhibited the exercise of discretion in the prison discipline process.

\section{Additional information}

A version of this paper was published as:

Schafer, N.E. (1986). "Discretion, Due Process and the Prison Discipline Committee." Criminal Justice Review 11(2): 37-46 (Fall 1986). 
DISCRETION, DUE PROCESS, AND THE PRISON DISCIPLINE COMMITTEE

by

N.E. Schafer

Justice Center

University of Alaska, Anchorage

JC 8518

Paper presented at the annual meeting of the Academy of Criminal Justice Sciences, Las Vegas, April 1985. 
Prison discipline received considerable attention from both the courts and professional organizations during the decade of the 70's. It was widely assumed that the due process requirements which resulted from judicial review coupled with the promulgation of model discipline standards and procedures would limit the broad discretionary authority traditional in the prison discipline process. A case study of the activities of one Prison Discipline Committee suggests that these external pressures have had less impact on decision-making than such internal pressures as overcrowding - Due process requirements have not greatly inhibited the exercise of discretion in the prison discipline process. 
Prison discipline had been, until the decade of the 70's, an internal prison matter governed by the practical considerations involved in maintaining institutional control. The discipline process came under external review at a time when increasing prison populations were creating concerns about potential disorder in the prison. Both the courts and corrections professionals created rules and procedures intended to inject minimum due process into prison discipline procedures and to limit the broad discretionary authority of the Prison Discipline Committee.

A descriptive study of the activities of one Prison Discipline Committee, operating under model procedures during a period of rapid growth in the prison population, suggests that the impact of these external pressures for change has not been as great as had been assumed. The committee retains broad discretion in exercising its authority and appears more responsive to internal pressures than to external ones. The data also reveal that the discipline process is more complex than either court decisions or corrections standards reflect and that the strategies utilized in the criminal court process can be appropriated for use in the prison discipline process.

The Prison Discipline Committee (PDC) plays a major role in the process of maintaining institutional control. This role has become increasingly important as unprecedented increases in the nation's prison population have led to fears that crowded prisons will dissolve into disorder. The prison's efforts to establish and maintain order rely heavily upon the formal enforcement of prison rules and regulations and upon the deterrent effect of the 
sanctions imposed on prisoners who violate these rules and regulations. It is the responsibility of the Prison Discipline Committee to oversee enforcement of the rules, to hold hearings to determine the guilt of the inmate charged with a violation, and to impose sanctions on adjudicated violators.

Until quite recently PDC's were free to perform their duties in a perfunctory manner with little regard for the fairness of their procedures or the aptness of the penalty. Courts had been loath to intervene in all prison problems and on the enforcement of prison rules and regulations deferred to the expertise of prison administrators. As recently as 1965 a federal court found whipping per se did not violate the Eighth Amendment although it established that corporal punishment should not be excessive and should be applied by "reasonable standards" (Talley v. Stephens, 1965). Three years later use of the strap (and all corporal punishment) was found violative of the Eighth Amendment (Jackson v. Bishop, 1968) and the federal courts began to intervene in other issues tied to abuses of the prison discipline process (e.g., Sostre v. Rockefeller, 1970; Morris v. Travisono, 1970; Wright v. McCann, 1972). Most of these early decisions dealt primarily with establishing minimal due process requirements in prison discipline proceedings and/or regulating the conditions of solitary confinement as a dispostion for rule violations.

The lower courts were divided on the issue of due process in prison discipline hearings, some denying even minimal requirements, others arguing that all the due process requirements in Morrissey v. Brewer (1972) vis-a-vis parole were appropriate in 
prison discipline hearings. The Supreme Court, in Wolf $v$. McDonnell (1974), clarified the issue and established minimal due process in cases involving substantial penalties lloss of good time and solitary confinement). Included were advance written notice of the charges and a written statement of evidence relied on and reasons for the sanction imposed. The Court assumed an impartial hearing board and suggested assistance for illiterate inmates though this was not tied to the initial complaint. Limits were placed on the right to call or cross-examine witnesses which was to be permitted "only if it will not be unduly hazardous to institutional safety or correctional goals."

By 1979 the Court seemed to have come full circle, implying in Bell v. Wolfish (1979) a return to the "hands off" doctrine. In this decision the court recommended deference to the professional expertise of prison officials and approved those practices which "in their judgment are needed to preserve internal discipline and order and to maintain institutional security" (emphasis added).

During the period when the courts were struggling with due process in prison discipline there was a parallel movement toward a justice model in all areas of criminal justice (American Friends Service Committee, 1972; National Advisory Commission on Criminal Justice Statndards and Goals, 1973; Fogel, 1975; et al). The justice or "just deserts" philosophy influenced the development of model rules and standards governing all aspects of prison discipline. These included the basic rights established by the courts as well as recommendations which went beyond those which 
the courts required. The following widely accepted policies on prison discipline have been extracted from three sources: The National Advisory Commission on Criminal Justice Standards and Goals, Corrections (1973); Krantz et al., Model Rules and Regulations on Prisoner Rights and Responsibilities (1973); and the Commission on Accreditation for Corrections, Manual of Correctional Standards for Adult Correctional Institutions ( 1977 ).

1. Written (and widely disseminated) rules and regulations which include the range of possible sanctions for each violation.

2. Distinctions between major and minor offenses vis-a-vis both permissible sanctions and the hearing process.

3. Written notice of the charges prior to the scheduled hearing (recommendations range from 1 to 5 days prior).

4. A pre-hearing investigation of facts in cases where the violation is a major one.

5. Availability of assistance for the prisoner in the preparation of his defense (may be staff, inmate or outsider).

6. An impartial hearing board.

7. The right of the inmate to present evidence/witnesses on his own behalf and confront witnesses against him.

8. Written guidelines for standard of proof (may be "preponderance of evidence" or "substantial evidence").

9. Written reasons for the decision.

10. Procedures for review and/or appeal of decision. 1

Recommendations that infractions be categorized by offense severity and that permissible sanctions be indicated for each category of rule violation exemplify the effort to incorporate a just deserts model into disciplinary procedures. An effort is 
made to tie an appropriate (just) sanction to each offense. The procedures do not include the limitations specified in Wolff $v$. McDonnell, 418 US 539 (1974), and thus go beyond what the courts required.

Neither the courts nor the standards have dealt with the legitimacy of prison rules and regulations, and, except for recommending specified sanctions for each category of offense, they have not paid attention to the aptness of the penalties. Corporal punishment has been abolished as a formal sanction and the conditions of solitary confinement have been regulated by the courts. They have not, however, ruled on its use as a sanction for any rule violation. In theory it can be imposed for any infraction from assault or escape to using obscene language or being untidy. It is the amount of time spent in segregation (duration of the sanction) which is tied to the severity of the offense (Wright v. McMann, 1970).

\section{Background of the Study}

While time in "the hole" is a favorite Hollywood version of prison punishment there are several other possible sanctions for prison rule violations. The options have not changed greatly since they were listed and described in the 1966 edition of Manual of Correctional Standards (ACA, 1966). Acceptable dispositions include: extension of release date through loss of "good time" or changes in credit time classification; punitive segregation (in a special restrictive unit or in solitary confinement), in-cell lockup, loss of privileges, restitution or reparation, extra work, transfer to another facility, and reprimand. Since 
these may be used singly or in combination the range of dispositions from which the Prison Discipline Committee can choose is quite broad. The Committee also determines the duration of the sanction which can range from a few days to months or even years. Sanctions can be suspended and when multiple sanctions are imposed the committee can order that these be served concurrently or consecutively. A review of the literature shows us that the discretionary power retained by the Prison Discipline Committee (PDC) is considerable and appears only minimally affected by court ordered due process requirements or by adherence to model procedures.

Research on prison discipline and discipline committees is not profuse. Fox (1958) analyzed prison discipline problems and included a ranking of sanctions by the frequency with which they were imposed by "custodial summary courts." No empirical data were presented since the author's concern was to discuss a range of problems. In the 1950's corporal punishment was a formal sanction in many southern states and, according to Fox, an informal sanction elsewhere. While this discussion of prison discipline is of interest, two contemporary studies of discipline in American are relevant to an assessment of discretion in the discipline process. ${ }^{2}$

A very thorough investigation into disciplinary procedures at the Rhode Island Prison complex following the outcome of Morris v. Travisono was conducted by the Harvard Center for Criminal Justice (1972). In an effort to analyze the impact of the court ordered due process requirements the Center analyzed nearly 700 
rule violations and more than 800 dispositions, conducted interviews, and observed at disciplinary hearings. Little correlation was found between disposition and type of misconduct and a number of situations were noted where committee member bias influenced both the determination of guilt and the sanctions imposed.

In a more recent study of discretion in prison justice, Flanagan (1982) attempted to identify the factors which influenced discipline committees' decisions in the New York state prison system. Using the misconduct records of a sample of individual prisoners he analyzed discretionary decision-making in relation to such prisoner characteristics as age, marital status, and prior discipline history. The association he reported between disposition and such demographic characteristics implies support of the observation by the Harvard Center that personal knowledge of the rule violator may be a factor in the PDC's decisions. Data from both of these studies suggest that the prison Discipline Committee exercises broad discretion in the disposition of cases of rule violation.

Disposition data from the Harvard Center study, the Flanagan study, Fox and the present study show the broad range of sanctions available to the PDC and reveal changes in the frequency with which they are imposed. The sanctions are displayed for comparison in Figure 1.

\section{Figure 1 about here}

The 1958 Fox study provided frequency rankings only. They were based on the author's study of prisons across the country 
and were presented as national rankings although no data were provided. It is not, therefore, particularly useful although it does suggest some changes in the last 25 years.

The New York system rankings are based on Flanagan's (1982) sample from several New York prisons. The data were collected over a three year period and were initially collected for a comparison of misconduct records between long-term and short-term prisoners. Although the source of the data, the method of collection, and the length of the data gathering period differ from those of the Rhode Island and Indiana studies, Flanagan's findings may be assumed to reflect the level of disciplinary discretion throughout the system. His results may, of course, be limited by differences in custodial setting and differences in the composition of the committees.

The Rhode Island Prison Complex rankings were derived from data collected during the summer of 1972 and included all decisions made by the Board during that period (Harvard Center, 1972). The Indiana study collected data from a single maximum security institution and also included all charges and decisions made during an even longer period. Flanagan noted that one of the chief differences between this study and his own was that he found a significant relationship between offense severity and severity of disposition, while the Harvard Center study found no relationship (p. 226). The Indiana study also differed in this regard from the Rhode Island one.

Each of the three studies was done during a period when the 
dispositions available to Prison Discipline Committees were fairly uniform yet rankings show considerable variation in the frequency with which the more severe sanctions were imposed. The most severe sanctions are extension of release date (through loss of "good time," change in classification, etc.) and disciplinary confinement (in a special maximum security unit). Together these were the most common dispositions at the Rhode Island Prison Complex ( $45 \%$ of total sanctions imposed), the least common in New York ( $6.7 \%$ of total sanctions) and relatively uncommon in Indiana (25\% of total sanctions). Extension of release date was imposed in Rhode Island in $18 \%$ of the cases, in New York in only $2.1 \%$ of the cases, and in Indiana in $5.7 \%$ of total cases. While punitive segregation was the most frequently imposed sanction in Rhode Island, the most common sanction in both New York and Indiana was in-cell restriction (29.9\% in New York and 41.98 in Indiana).

One might conclude from the clear differences revealed in Figure 1 that the procedural changes mandated by the courts or recommended by professional organizations had had an impact on decision-making in the prison discipline process. Certainly there was a change in the frequency with which the "substantial penalties" identified by the courts were imposed. There was a considerable decrease between 1972 and 1980-81 in the imposition of both extension of release date and punitive segregation. It should be noted, however, that judicial review was occurring at a time when prison populations were growing. The imposition of these "substantial penalties" might have changed in response to the internal pressures of crowding rather than the external 
pressures of court decisions. (Neither New York nor Indiana was directly affected by judicial review.) It should be noted that the population of the Rhode Island Prison Complex was below official capacity in 1973, the nearest year for which data were available (ACA, 1977), while the Indiana Prison was above capacity for the entire research period and the New York system was experiencing crowding in the mid-seventies.

Major shifts in justice policies nationally were occurring during the decade covered in Figure 1. Since 1975, several states have changed their penal codes to provide for definite sentences and some have enacted mandatory sentences for certain offenses. There has also been a trend toward longer sentences in legislatures and the courts. One result has been overcrowding in most American prisons.

The Prison Discipline Committee must be sensitive to the problem of crowding and must avoid the imposition of sanctions which will exacerbate the problem as prolific use of extension of release date would. In-cell restriction appears to be an alternative to punitive segregation. Since the punitive segregation unit has a finite capacity a similar alternative which does not require additional bed space may be substituted.

A closer examination of decision-making in matters of prison discipline is necessary before the differences in disposition illustrated in Figure 1 can be attributed to the impact of judicial review, new standards, or to the need to deal with the realities of expanding prison populations. 
$\underline{\text { Prison Discipline in Indiana }}$

Indiana revised its penal code in 1977 which, some claimed, would result in longer average sentences and thus overcrowding (Clear et al., 1978). The code provided for definite sentences and a form of presumptive parole which provided credit time of one day off the sentence for each day served and included credit for pre-trial jail time. Using this formula, a presumed release date is figured for each prisoner upon entry into the prison system. The presumed release date will fall no more than half way through the definite sentence imposed by the court. The release date will not change unless the prisoner's institutional behavior warrants a change to a different credit class (one day for every two days served or no days). The amount of the sentence actually served can thus be as much as doubled by the actions of the Prison Discipline Committee. Although this provision of the penal code gives prison authorities considerable power over the amount of the sentence which is actually served, the code also requires due process hearings and an appeal procedure. Because the predicted prison overcrowding has occurred, prison authorities use this power sparingly and appeals often result in reinstatement.

The due process required by the penal code has been incorporated into the Prison Discipline procedures developed by the Department of Correction. These procedures conform to the model standards developed nationally (see above). The procedures include a list of rules and regulations and the possible sanctions for violation of these. There are 75 specific violations 
which have been divided, not just into major and minor offenses as the standards suggest, but into four categories, A, B, C, and D violations, with A being the most serious and $D$ the least serious. (See complete list in Appendix.) As do most prison manuals it includes a "catch-all" violation which is a class D offense - \#158, "Violating any institutional rule, regulation or standing order, if said rule. - has been communicated to the inmate." (Department of Correction, 1980:28). Disposition guidelines are provided for each category of violation.

The procedures stipulate a three member Conduct Adjustment Board with a rotating membership. One member must be from the custodial staff and one member from the treatment staff. At the prison studied the Conduct Adjustment Board (or PDC) resolves all formally charged rule violations (all "write-ups"). Essentially the process is: (1) a "write-up" by staff stipulating the rule violated; (2) unless the violation is a serious one, appearance of the prisoner before the Prison Discipline Committee occurs within days of the charge; (3) the prisoner enters a plea and, if the plea is not guilty, there is a discussion of the violation with the offender and, if necessary, the officer and witnesses may appear as well; and (4) the PDC makes a decision and imposes a sanction. If charges are serious there are provisions for prehearing detention, there is a formal investigation, and the appearance may be considerably delayed while evidence is sought.

\section{Case Study of an Indiana Prison Discipline Committee}

Data were collected from daily reports of the prison Disciplinary Committee of a maximum security facility over an 
1l-month period from July, 1980 to June, 1981. The data included prisoner identifiers, prisoner housing unit, the violation, the date of the violation, the plea and the disposition. These were processed and the preliminary results have been analyzed.

During the eleven month data collection period 4,339 rule violations were reported: 250 Class A violations, 1,298 Class B violations, 958 Class C violations and 1,727 Class D violations, and 6 other. Although this appears to represent an average caseload for the PDC of 394 violations per month, in fact the 4,339 violations were committed by 1,201 prisoners for a caseload average of 109 per month.

All of the cases which came before the committee were not straightforward: an infraction, a write-up, a hearing, and a disposition. Some prisoners were chronic rule violators and appeared frequently and regularly during their sentences. Other prisoners received multiple charges or write-ups from a single incident (analogous to filing multiple charges in a criminal court). While the average number of violations per violator was 3.6, a substantial percentage of the violators had only one write-up during the research period. Thus, $39.8 \%$ of the violators ( $N=479$ ) accounted for 118 of the violations $(N=479)$. Of the 1,201 prisoners receiving write-ups, 93 (7.78) had 10 or more violations during the research period but this small percentage of violators accounted for 1,367 or 31.58 of the total violations. Many of the cases heard by the committee are thus quite complex. 
Disposition data provide the best empirical basis for assessing the activities of the PDC. While a summary of disposition frequency has been presented in Figure 1, a closer look is warranted. In Figure 2, Dispositions are listed by offense category and the dispositions are also more carefully defined: e.g., in Figure 1 a disposition which combined restriction with loss of privileges has been incorporated into the restriction category; in Figure 2 it has been separated. "Other" categories are also specified; 64 prisoners were required to pay damages; some for lost library books, some for state property they altered or destroyed. In only 14 cases did the PDC make the disposition equal to time already served in pre-hearing detention.

\section{Figure 2 about here}

Revocation of a previously suspended sentence was, regretfully, not coded. Suspension of the instant offense was coded but suspensions are listed under the sanction suspended on the chart. There were only 38 suspended dispositions; 36 punitive segregation sanctions; two in-cell restrictions.

It is clear from Figures 1 and 2 that extension of release date (change of credit class or loss of earned time) was seldom imposed. This disposition was assigned for only $5.8 \%$ of all violations. In $30(49.18)$ of the 61 imposed for Class $A$ offenses extension of release date was imposed in addition to another sanction; in 113 (84.38) of those imposed for Class B offenses this sanction was added to another disposition. It appears that it was imposed only for very serious violations and/or for 
multiple violations of a serious nature. The six imposed for Class D offenses were served concurrently with sanctions imposed for more serious violations. It must be inferred that the PDC is reluctant to keep prisoners beyond their presumed release date because of the extreme crowding the prison experienced both before and during the research period. (The average monthly population grew from 1,471 in July, 1980 to 1,712 in May, 1981.)

Clearly in-cell restriction was the most common disposition. It was used more than twice as often as punitive segregation (in special housing units). This may be because the Maximum Restraint Unit has a finite capacity. Since Class A or B violators may be segregated there for 6 months to three years this sanction was seldom imposed for Class C and D violations except when they were associated with more serious misconduct. The double penalty which adds loss of privileges to in-cell restriction appears to be an effort to make this sanction more closely approximate the more severe penalty of punitive segregation. It, too, reflects the need to accommodate for the limited capacity of the Maximum Restraint Unit and suggests that the difference in use of the "substantial penalties" illustrated in Figure 1 is more closely tied to capacity than to judicial restrictions.

While the frequency with which different dispositions are given for varying kinds of prison rule violations is an important means of assessing the prison discipline process, the duration of the disposition is more revealing of the discretionary nature of the process. The PDC has broad discretion to choose among several disposition alternatives, but its power to assign the 
length of time the disposition must be endured greatly increases its discretionary powers. It would be of interest to compare duration of sanction among prisons but none of the studies in the literature used this measure. The data can only be assessed within the context of the Indiana Committee's activities.

The published Prison Discipline procedures (Department of Correction, 1980) provided guidelines for choosing an appropriate disposition and listed maximum and minimum time limits for each sanction. Those dispositions which included the setting of durations are punitive segregation, in-cell restriction, and loss of privileges. Figure 3 illustrates the duration decisions made by the PDC. Data are presented by type and disposition for each violation category and the ranges and mean lengths of the sanctions are compared with departmental guidelines.

\section{Figure 3 about here}

Except for punitive segregation of Class D violators the means are within the available departmental guidelines for each violation category. Three years (1095 days) in punitive segregation was assigned in only 5 cases for Class D violators. In each case the violation was a part of multiple "write-ups" arising from the same incident and the disposition was served concurrently with a disposition for a very serious Class A violation. The extraordinary length of these five dispositions sufficed to skew the mean. Otherwise the means appear to reflect considerable uniformity in the disciplinary decisions of the PDC. The ranges, however, reveal exceptional cases in every category. 
Punitive segregation is an official disposition for all violations. The length of time spent in the Maximum Restraint Unit is the true test of the seriousness of the violation. Class A violations are the most serious offenses and include assault, escape, rioting, etc. The official guidelines reflect the seriousness of these violations and permit confinement in punitive segregation for one to three years. 3 The discretion of the PDC is evident in the duration of this sanction imposed for Class A offenses. Of the 127 Class A violators receiving this disposition, more than half $(\mathrm{N}=66)$ were for shorter periods than the guidelines recommend: five were for 30 days; six were for 60 days; 12 for 90 days; and the remainder were for 180 days. Although the departmental guidelines do not recommend other dispositions for Class A violations, in-cell restriction was imposed for 53 Class A violations and loss of privileges for four.

For B violations the PDC was clearly willing to mitigate the harshness of the prescribed penalty on a case-by-case basis. Though the trend toward mitigation is less definite for Class B offenses it does hold for punitive segregation. Twenty cases fell outside the departmental guidelines. Seven were above ( 365 days) and the rest below the prescribed range ( 8 were for one or two days).

Analyzing the duration data for Class C and D violations is complicated by the fact that many were part of multiple charges stemming from a single incident. of 128 Class C violations assigned punitive segregation, 21 were outside the prescribed range of 15-45 days. Seventeen were served concurrently with 
dispositions for other offenses. For both C and D violations assignment to punitive segregation tends to be for longer periods than those suggested by the Department of Correction. This disposition was relatively rare for minor violations and was assigned for only 13.48 of all Class C violations and 11.18 of all Class D violations.

In-cell restriction was the preferred disposition for these violation categories and was the assigned disposition for $46.2 \%$ of Class C and 43.98 of Class D violations. For this disposition, too, the range of the duration assigned by the PDC shows great variation when compared with the prescribed range. Departmental guidelines are not provided for duration of loss of privileges. For this disposition the range of durations assigned for B, C and D violations is similar to those for in-cell restriction, but the means tend to be quite a bit higher. Since loss of a privilege is considered a less severe disposition than in-cell restriction the greater lengths assigned may reflect an effort to make this sanction more punitive.

\section{$\underline{\text { Discussion }}$}

The prison discipline process has been characterized as arbitrary and capricious and a suitable area for court intervention. Federal courts have mandated minimal due process requirements for prison discipline proceedings but have not dealt with the nature of prison rules and regulations or the appropriateness of the sanctions for violating these. The discretionary decision-making power of the Prison Discipline Committee has not been weakened by these court decisions although an appeal process may alter their 
decisions.

The PDC studied here clearly retained broad discretion in the exercise of its power. The dispositions available, the possibility of combining dispositions, and the authority to set the duration of each sanction provided a broad base for the exercise of discretion. The data reflect this but do not provide proof that the change in the use of substantial penalties was impacted by court decisions.

Since the PDC under study had not been directly affected by judicial review, i.e., had not been part of any suit related to prison discipline, it seems more likely that the change can be attributed to institutional realities the pressure of major population increases. A major question raised by such a conclusion is whether disposition patterns will change when the crowding problem is resolved. Crowding is not desirable and few prison employees would object to actions designed to relieve it. If a major reduction in population were to occur there might be an increase in the use of the "substantial penalties" of extension of release date and punitive segregation. The creative use of alternative dispositions demonstrated in Figures 2 and 3 suggests this possibility.

The PDC made broad use of sanctions which did not require additional space and used its discretion to combine these sanctions in order to increase their severity. The double sanction of in-cell restriction with loss of privileges appears to be an effort to assign a penalty as severe as punitive segregation. 
Reassignment to the Maximum Restraint Unit restricted prisoner movement, but did not include loss of privileges. Confinement to one's cell (or dormitory) also restricted movement; when combined with loss of privileges, this disposition is quite substantial. This combined disposition often included separate lengths for each part, with restriction being the longer portion of the sanction. For this reason and because there were only 110 cases of double penalty these were coded under in-cell restriction in Figure 3. The maximum length was coded and the 110 double sanction cases have been included in the duration table (Figure 3) under the in-cell restriction category.

It should also be noted from Figure 3 that what is considered the mildest penalty (loss of privilege) is imposed for considerably longer periods than in-cell restriction for all but A violations. Although there is a hierarchy of penalties ranging from substantial to mild the duration assigned implies an effort to equalize the lesser penalties. The duration data thus reflects broad use of discretionary authority and is a very useful means of assessing the discretion exercised by prison discipline committees. Future studies of the prison discipline process should include this measure. The discretion data collected in the study cannot indicate the basis of each kind of discretion exercised by the PDC but they do demonstrate that discretion was being exercised and that it was intended to increase the penalty in some cases and to mitigate the harshness of prescribed penalties in others.

For nearly every category of violation the range of durations 
assigned has a lower minimum than that prescribed by the Departmental Guidelines (Figure 3). The differentials at both ends of the ranges suggest decision-making on a case-by-case basis. Not all discipline cases are simple and straightforward; many require careful consideration and some charges require interpretation. Assault, a Class A violation, serves as an example.

The charge of assault is entered whether the victim was a prisoner or a staff member, but the disposition may not be the same. The initial charge is entered regardless of the outcome of the hearing. It may be determined from witnesses that what an officer saw as an assault was actually the end of an unequal fight (a Class B violation) and sanctions must be altered accordingly. Where the assault occurred adds another dimension to the complexity of the case. In this study assaults occurred in cell blocks and dormitories, the school, and the infirmary. One occurred at a Discipline Hearing and another in the Superintendent's office. Disposition decisions will take into account a variety of factors.

The PDC at the Indiana Reformatory operated under procedures which went beyond the minimum due process mandated by court decisions. All violators, not just those in danger of substantial penalties, had the opportunity for a hearing. None of the committee members interviewed could recall a case where security had been invoked to prevent the calling of witnesses as Wolff $v$. McDonnell permits. The procedures as written in the Department of Correction Manual (1982) fully conformed to the model 
discipline procedures specified by professional organizations (see above, p. 4). While conformance to court decisions and published standards did provide procedural safeguards they did not greatly limit the broad discretionary authority of this Prison Discipline Committee as evidenced by the duration data. These data suggest that the committee was impacted to a greater degree by the internal institutional reality of increased population than by external pressures to provide a "just" disciplinary process. 
Figure 1: A COMPARISON OF DISPOSITION FREOUENCY

\begin{tabular}{|c|c|c|c|c|c|c|c|c|c|c|}
\hline Disposition & $\begin{array}{l}\text { National } \\
\text { Rankings }\end{array}$ & \multicolumn{3}{|c|}{$\begin{array}{l}\text { Rhode Island } \\
\text { Prison Complex }\end{array}$} & \multicolumn{3}{|c|}{$\begin{array}{c}\text { New York State } \\
\text { Facilities }\end{array}$} & \multicolumn{3}{|c|}{$\begin{array}{r}\text { Indiana } \\
\text { Prison }\end{array}$} \\
\hline & 1957 & \multicolumn{3}{|c|}{1972} & \multicolumn{3}{|c|}{$1973-76$} & \multicolumn{3}{|c|}{$1980-81$} \\
\hline & (Rank only) & Rank & $\#$ & q & Rank & \# & 8 & Rank & $\#$ & 8 \\
\hline Extension of & 6 & $2 / 3$ & 155 & 18 & 6 & 13 & 2.1 & 5 & 250 & 5.7 \\
\hline \multicolumn{11}{|l|}{ Punitive } \\
\hline Referrala & & 5 & 83 & 10 & & NA & & & NA & \\
\hline \multicolumn{4}{|l|}{ In-cell } & 6 & 1 & 184 & 29.9 & 1 & 1818 & 41.9 \\
\hline $\begin{array}{l}\text { Loss of } \\
\text { Privileges }\end{array}$ & 3 & 4 & 88 & 10 & 3 & 112 & 18.3 & 4 & 552 & 12.7 \\
\hline Transfer & 4 & 7 & 39 & 5 & & NA & & 7 & 6 & .0 \\
\hline \multicolumn{2}{|l|}{$\begin{array}{l}\text { Warning/Reprimand } \\
\text { Suspended Sentence }\end{array}$} & $2 / 3$ & 155 & 18 & 2 & 151 & 24.4 & 3 & 641 & $14.7^{b}$ \\
\hline Lahor Squad & 5 & & $\mathrm{NA}$ & & & NA & & & NA & \\
\hline Corporal Punishment & 7 & & NA & & & NA & & & $\mathrm{NA}$ & \\
\hline other & & 8 & 20 & 2 & 4 & 107 & 17.5 & 6 & 78 & 1.7 \\
\hline (Acquittal) & $\mathrm{NA}$ & & $(36)$ & 4 & & $(20)$ & 3.2 & & (157) & $3.7^{b}$ \\
\hline TOTALS & & & 862 & 100 & & 615 & 100 & & 4339 & $99.7 \mathrm{C}$ \\
\hline \multicolumn{11}{|c|}{$\begin{array}{l}\text { a Referral to the classification committee. Segregation or change in } \\
\text { implied. Neither of the other states had a similar disposition. } \\
\text { b several cases were found where a reprimand was given even when no vi } \\
\text { Coders had used their discretion in coding so some may appear in the } \\
\text { c Does not total } 1008 \text { due to rounding. }\end{array}$} \\
\hline
\end{tabular}


FIGURE 2: DISPOSITIONS IMPOSED BY CATEGORY OF OFFENSE

\begin{tabular}{|c|c|c|c|c|c|}
\hline $\begin{array}{c}\text { DIS POS ITION } \\
\text { RANKED BY SEVERITY } \\
\end{array}$ & CLASS A & CLASS B & CLASS $\mathrm{C}$ & CLASS D & TOTAL \\
\hline $\begin{array}{l}\text { Extension of Release Date } \\
\text { A. (Change Credit Class) } \\
\text { B. (Loss of Time Earned) }\end{array}$ & $\begin{array}{r}61 \\
(53) \\
(8)\end{array}$ & $\begin{array}{r}134 \\
\quad(121) \\
(113)\end{array}$ & $\begin{array}{r}49 \\
(46) \\
(3)\end{array}$ & $\begin{array}{l}6 \\
(3) \\
(3)\end{array}$ & $\begin{array}{r}250 \\
(223) \\
(27)\end{array}$ \\
\hline Punitive Segregation & 127 & 389 & 128 & 193 & 837 \\
\hline $\begin{array}{l}\text { Restriction with Loss of } \\
\text { Privileges }\end{array}$ & 4 & 38 & 27 & 41 & 110 \\
\hline Restriction & 49 & 523 & 418 & 718 & 1708 \\
\hline Loss of Privileges & 4 & 112 & 139 & 297 & 552 \\
\hline Restitution/Pay Damages & 1 & 38 & 13 & 12 & 64 \\
\hline Time Served 1 & 3 & 6 & 3 & 2 & 14 \\
\hline Warning, 2 Reprimand & 0 & 137 & 133 & 377 & 641 \\
\hline Acquittal 2 & 1 & 21 & 48 & 87 & 157 \\
\hline TOTALS & 250 & 1398 & 958 & 1733 & 4339 \\
\hline $\begin{array}{l}1 \text { Detention time served awaiting } \\
2 \text { There may be overlap here. Ma } \\
\text { reprimands which led to coding }\end{array}$ & $\begin{array}{l}\text { disciplinary } \\
\text { ny acquittals } \\
\text { confusion. }\end{array}$ & $\begin{array}{l}\text { court was } \\
\text { were accor }\end{array}$ & $\begin{array}{l}\text { equivalent } \\
\text { npanied by }\end{array}$ & $\begin{array}{l}\text { to disposition } \\
\text { verbal warnings }\end{array}$ & time. \\
\hline
\end{tabular}


FIGURE 3: LENGTH (in days) BY DISPOSITION AND TYPE OF OFFENSE

\begin{tabular}{|c|c|c|c|c|}
\hline $\begin{array}{l}\text { Disposition and } \\
\text { Type of of } f \text { ense }\end{array}$ & $\begin{array}{l}\# \text { of } \\
\text { cases }\end{array}$ & Range & Mean & $\begin{array}{l}\text { Departmental } \\
\text { Guidelines }\end{array}$ \\
\hline \multicolumn{5}{|l|}{ Punitive Segregation } \\
\hline $\begin{array}{ll}\text { Class } & A \\
\text { Class } & B \\
\text { Class } & C \\
\text { Class } & D\end{array}$ & $\begin{array}{l}127 \\
389 \\
128 \\
193\end{array}$ & $\begin{array}{l}30-1095 \\
1-365 \\
2-180 \\
1-1095\end{array}$ & $\begin{array}{r}392.32 \\
98.53 \\
40.07 \\
61.28\end{array}$ & $\begin{array}{c}365-1095 \\
30-180 \\
15-45 \\
1-30\end{array}$ \\
\hline \multicolumn{5}{|l|}{ In-Cell Restriction } \\
\hline $\begin{array}{ll}\text { Class } & A \\
\text { Class } & B \\
\text { Class } & C \\
\text { Class } & D\end{array}$ & $\begin{array}{r}53 \\
560 \\
443 \\
761\end{array}$ & $\begin{array}{l}2-60 \\
1-90 \\
1-60 \\
1-60\end{array}$ & $\begin{array}{r}35.57 \\
22.70 \\
16.33 \\
9.41\end{array}$ & $\begin{array}{c}\text { Not Suggested } \\
15-60 \\
15-30 \\
1-30\end{array}$ \\
\hline \multicolumn{5}{|l|}{ Loss of Privileges } \\
\hline $\begin{array}{ll}\text { Class } & A \\
\text { Class } & B \\
\text { Class } & C \\
\text { Class } & D\end{array}$ & $\begin{array}{r}4 \\
112 \\
139 \\
297\end{array}$ & $\begin{array}{l}7-60 \\
1-90 \\
1-60 \\
1-30\end{array}$ & $\begin{array}{l}27.75 \\
25.71 \\
24.38 \\
18.09\end{array}$ & $\begin{array}{l}\text { NA } \\
\text { NA } \\
\text { NA } \\
\text { NA }\end{array}$ \\
\hline $\begin{array}{l}1 \text { Loss of privileges } \\
\text { Procedures Manual. }\end{array}$ & is not & included in & the Disc & plinary \\
\hline
\end{tabular}


NOTES

1 There are usually two steps in the appeals process. The first is an inside review; the second, an appeal to a state grievance board which often includes "citizens," i.e., persons not affiliated with the prison system. For a discussion of this process see Brakel (1983) who noted that 55 of 81 grievances heard by the Illinois Grievance Board concerned disciplinary infractions. Appeal procedures vary widely from state to state and in some limits are placed on the grievablity of disciplinary decisions.

2 A study by Dauber and Sichor (1979) compared disciplinary practices at an American prison (Rhode Island) with those at an Israeli one. They concluded that the Israeli prison was more lenient though officially less concerned with due process. Since this study included data from the Israeli prison only it is not relevant to the present study due to differences between Israel and the United States vis-a-vis legal systems and prison policies.

3 These guidelines seem unusually high. The Harvard Center reported that Morris $v$. Travisono placed a thirty day limit on the duration of any specific sanction (1972:214n). 
REFERENCES

AMERICAN CORRECTIONAL ASSOCIATION

1966 Manual of Correctional Standards. Rockville, MD: ACA.

\footnotetext{
1977 Directory. College Park, MD.

AMERICAN FRIENDS SERVICE COMMITTEE

1972 Struggle for Justice. New York: Hill and Wang.

BARKEL, S.J.

1983 "Ruling on Prisoners' Grievances," American Bar Foundation Research Journal 1983(2):393-425.

CLEAR, T.R., J. HEWITT and R.M. REGOLI

1978 "Discretion and the Indeterminate sentence," Crime and Delinquency $24(4): 428-45$.

COMMISSION ON ACCREDITATION FOR CORRECTIONS

1977 Manual of Standards for Adult Correctional Institutions. Rockville, MD: ACA.
}

DAUBER, E and D. SCHICHOR

1980 "A Comparative Exploration of Prison Discipline," Journal of Criminal Justice 7(1):21-36.

FLANNAGAN, T.A.

1982 "Discretion in the Prison Justice System," Journal of Research in Crime and Delinquency 2(2):216-37.

FOGEL, D.

1975 We are the Living Proof, Cincinnati: W.H. Anderson Co.

FOX, V.

1958 "Analysis of Prison Discipline Problems," Journal of Criminal Law, Criminology and Police Science $49(4): 321-2 \frac{\text { b. }}{4}$ Police

HARVARD CENTER FOR CRIMINAL JUSTICE

1972 "Judicial Intervention in Prison Discipline," Journal of Criminal Law, Criminology and Police Science $62(3) 200-228$

INDIANA DEPARTMENT OF CORRECTIONS

1980 Prison Discipline Procedures.

KRANTZ, S., R.A. BELL, J. BRANT and M. MAGRUDER

1973 Model Rules and Regulations on Prisoners Rights and Responsibilities. St. Paul, mN $\overline{\text { West Publishing Co. }}$ 


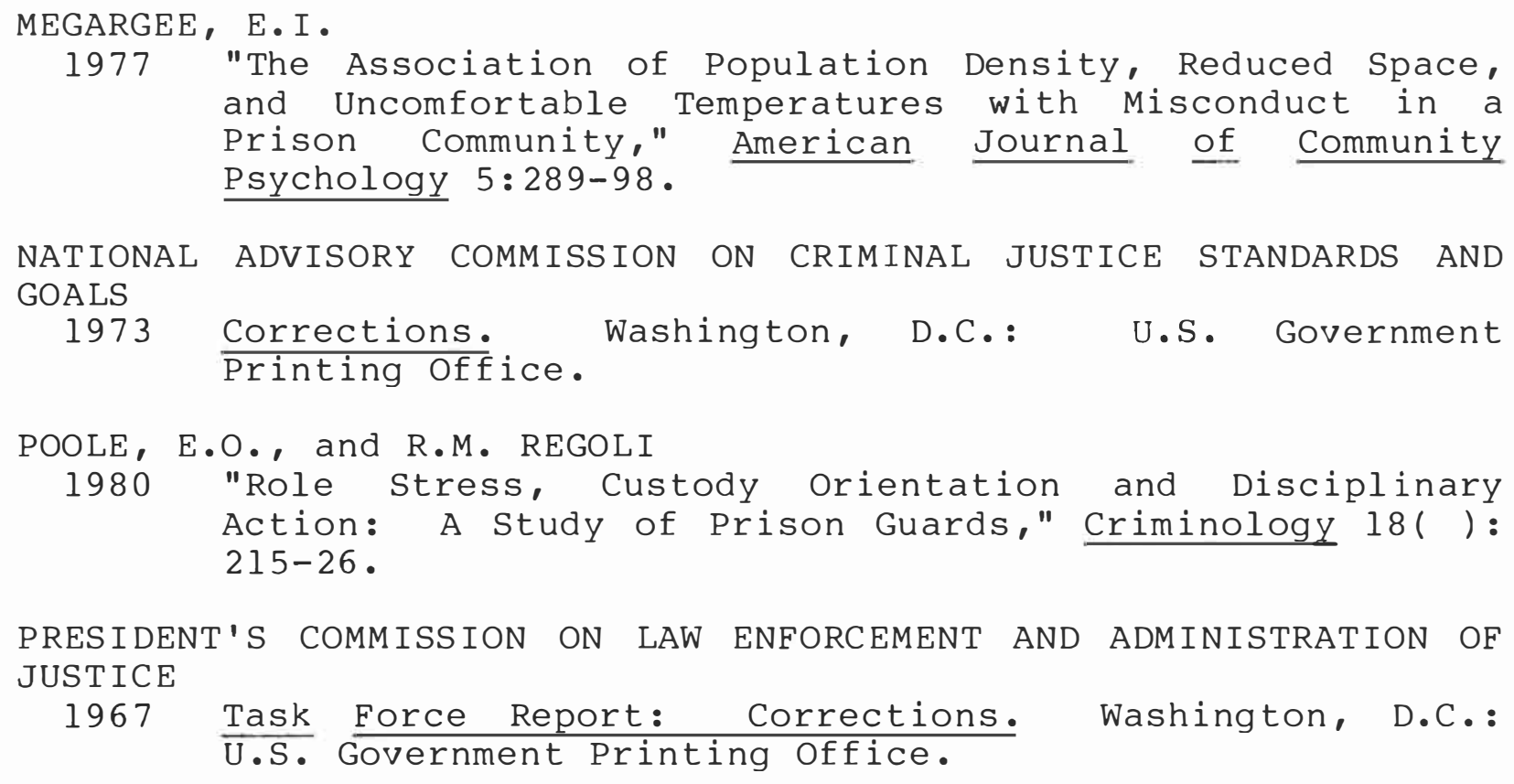

NATIONAL ADVISORY COMMISSION ON CRIMINAL JUSTICE STANDARDS AND GOALS

1973 Corrections. Washington, D.C.: U.S. Government Printing Office.

POOLE, E.O., and R.M. REGOLI

1980 "Role Stress, Custody Orientation and Disciplinary Action: A Study of Prison Guards," Criminology 18( ): $215-26$.

PRESIDENT'S COMMISSION ON LAW ENFORCEMENT AND ADMINISTRATION OF JUSTICE

1967 Task Force Report: Corrections. Washington, D.C.: U.S. Government Printing Office. 


\section{CASES}

Baxter v. Palmingiano, 96 S.Ct. 1551 (1976).

Bell v. Wolfish, 99 S.Ct. 1861 (1977).

Clutchette v. Procunier, 328 F.Supp. 761 (N.D. Cal, 1971).

Jackson v. Bishop, 404 F.2d 571 (8th Cir. 1970).

Morris v. Travisono, 310 F.Supp. 857 (D.R.I. 1970).

Talley v. Stephens, 247 F.Supp. 683 (E.D. Ark. 1965).

Sostre v. Rockefeller, 312 F.Supp. 863 (S.D.N.Y. 1970).

Wright v. McMann, 460 F.2d 126 (2d Cir. 1972).

Wolff v. McDonnell, 418 U.S. 539 (1974). 
APPENDIX 
LIST OF VIOLATIONS

\section{CLASS A}

100 Commission of a Class or B felony

101 Homicide

102 Assault or assault and battery

103 Rioting

104 Sexual Assault

105 Habitual Conduct Rule violator

106 Possession, introduction or use of an explosive or any ammunition

107 Possession, introduction or use of a dangerous or deadly weapon

108 Escape

175 Attempting to commit any of the above

\section{CLASS B}

109 Fighting

110 Threatening another with bodily harm

111 Extortion, blackmail, protection

112 Destroying, altering or damaging state property

113 Engaging in sexual acts

114 Making sexual proposals

116 Possession or introduction of literature or plans regarding an explosive or ammunition

117 Possession or introduction of literature or plans regarding a dangerous or deadly weapon

118 Possession of escape paraphernalia

119 Possession, introduction or use of any unauthorized narcotic drug, faraphernalia or contrclled substance

120 Wearing a disguise or mask

121 Setting a fire without authorization

122 Encouraging others to riot

123 Stealing (Theft)

124 Tampering with, altering, or blocking any locking device

125 Unauthorized alteration of any food or drink

126 Unauthorized possession or introduction of any device capable of being used as a weapon

127 Possession of any officer's or staff clothing (unauthorized)

128 Engaging in or encouraging others to engage in a group demonstration

129 Counterfeiting, forging, or unauthorized reproduction of any document, article, etc.

130 Making intoxicants or possession of intoxicants

131 Being intoxicated

132 Gambling

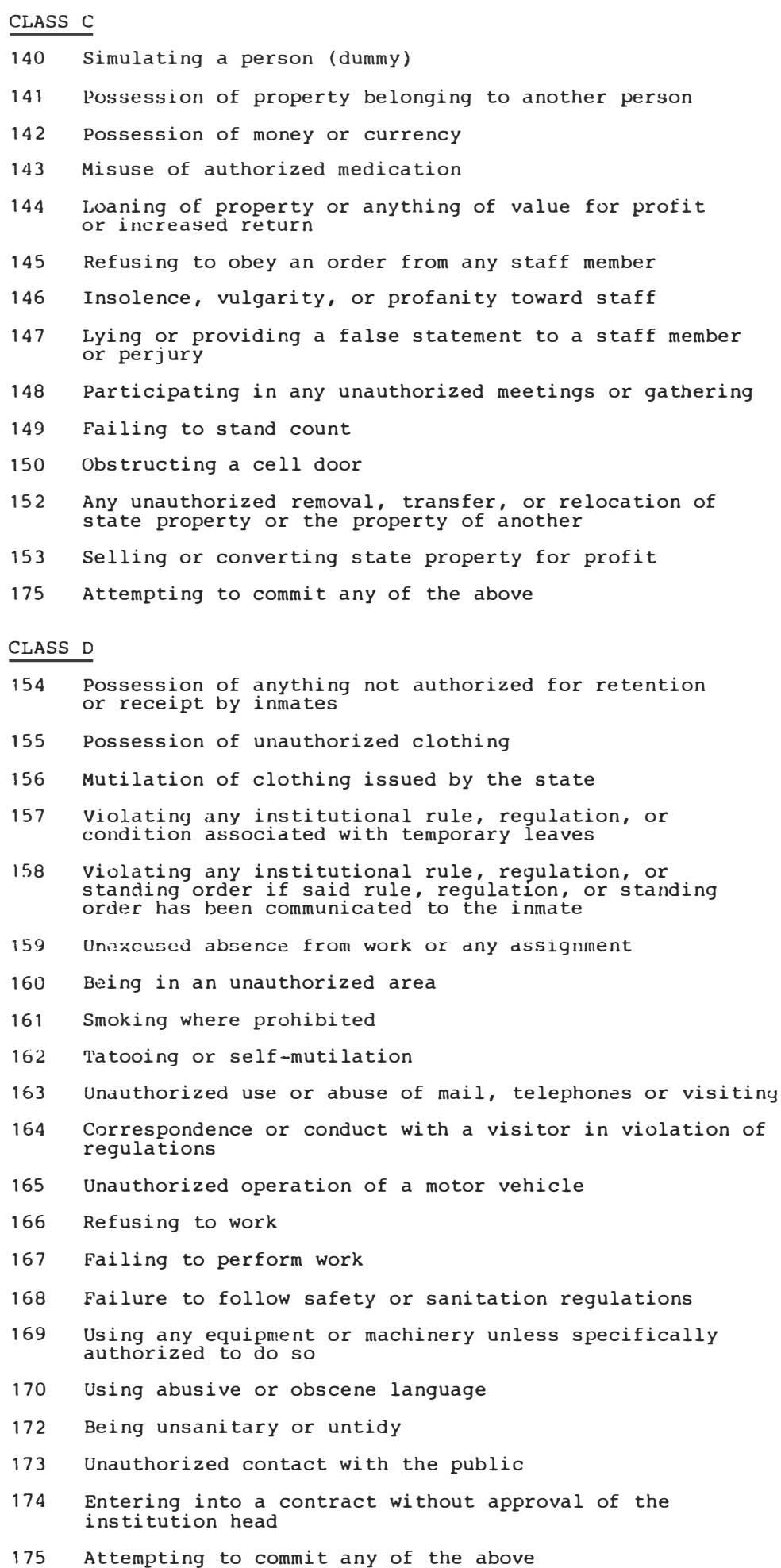

Source: Indiana Department of Corrections 